\title{
Complement Fixation Assay
}

National Cancer Institute

\section{Source}

National Cancer Institute. Complement Fixation Assay. NCI Thesaurus. Code C154799.

An in vitro immunoassay that measures the binding of complement to antigen-antibody complexes in serum, leading to the depletion of free complement and the reduction of hemolytic activity. 